\title{
Kefir induces cell-cycle arrest and apoptosis in HTLV-I-negative malignant T-lymphocytes
}

\author{
This article was published in the following Dove Press journal: \\ Cancer Management and Research \\ II February 2011 \\ Number of times this article has been viewed
}

\section{Katia Maalouf' \\ Elias Baydoun ${ }^{2}$ \\ Sandra Rizk'}

'Department of Natural Sciences, Lebanese American University, Beirut, Lebanon; ${ }^{2}$ Department of Biology, American University of Beirut, Beirut, Lebanon
Correspondence: Sandra Rizk

Department of Natural Sciences, Lebanese American University, P.O. Box 13-5053, Beirut I I02-280 I, Lebanon

$\mathrm{Tel}+96 \mid$ I 786456

Fax $+96 \mid$ I 867098

Email sandra.rizk@lau.edu.lb
Background: Adult lymphoblastic leukemia (ALL) is a malignancy that occurs in white blood cells. The overall cure rate in children is $85 \%$, whereas it is only $40 \%$ in adults. Kefir is an important probiotic that contains many bioactive ingredients, which give it unique health benefits. It has been shown to control several cellular types of cancer.

Purpose: The present study investigates the effect of a cell-free fraction of kefir on CEM and Jurkat cells, which are human T-lymphotropic virus type I (HTLV-1)-negative malignant T-lymphocytes.

Methods: Cells were incubated with different kefir concentrations. The cytotoxicity of the compound was evaluated by determining the percentage viability of cells. The effect of all the noncytotoxic concentrations of kefir on the proliferation of CEM and Jurkat cells was then assessed. The levels of transforming growth factor-alpha (TGF- $\alpha$ ), transforming growth factor- beta1 (TGF- $\beta 1$ ), matrix metalloproteinase-2 (MMP-2), and MMP-9 mRNA upon kefir treatment were then analyzed using reverse transcriptase polymerase chain reaction (RT-PCR). Finally, the growth inhibitory effects of kefir on cell-cycle progression/apoptosis were assessed by Cell Death Detection (ELISA) and flow cytometry.

Results: The maximum cytotoxicity recorded after 48-hours treatment with $80 \mu \mathrm{g} / \mu \mathrm{L}$ kefir was only $42 \%$ and $39 \%$ in CEM and Jurkat cells, respectively. The percent reduction in proliferation was very significant, and was dose-, and time-dependent. In both cell lines, kefir exhibited its antiproliferative effect by downregulating TGF- $\alpha$ and upregulating TGF- $\beta 1$ mRNA expression. Upon kefir treatment, a marked increase in cell-cycle distribution was noted in the preG $_{1}$ phase of CEM and Jurkat cells, indicating the proapoptotic effect of kefir, which was further confirmed by Cell Death Detection ELISA. However, kefir did not affect the mRNA expression of metalloproteinases needed for the invasion of leukemic cell lines.

Conclusion: In conclusion, kefir is effective in inhibiting proliferation and inducing apoptosis of HTLV-1-negative malignant T-lymphocytes. Therefore, further in vivo investigation is highly recommended.

Keywords: apoptosis, cancer, CEM, Jurkat, kefir, leukemia

\section{Introduction}

Adult lymphoblastic leukemia (ALL) is a malignancy that occurs in white blood cells allowing them to continuously multiply in the bone marrow. ALL is common both in children and adults and is classified into acute or chronic subtypes depending on the number of abnormal T-cells in peripheral blood. Patients with ALL show symptoms of weakness, fatigue, anemia, weight loss, excessive bleeding, and joint pain due to malfunctioning of their erythrocytes, leukocytes, and platelets. ${ }^{1}$ Different treatments for leukemia have been developed since the 1950s. The success of a treatment is 
measured as five-year, event-free survival rate. This survival rate is $70 \%$ to $83 \%$ in childhood ALL, whereas in adult ALL, the cure rates seldom exceed $40 \%$. Additional work is in progress to obtain better results in adult patients. Pediatric and adult oncologists are working together to develop a common treatment protocol for adolescents and young adults. ${ }^{2}$

Kefir is produced by adding kefir grains, which are similar to small cauliflower florets, to pasteurized milk. ${ }^{3}$ It differs from other milk products such as yoghurt, for example, because it is fermented with a mixture of bacteria and yeast confined to a matrix of discrete kefir grains recovered after fermentation. ${ }^{4,5}$ Kefir is viscous, slightly carbonated, and contains small quantities of alcohol. ${ }^{3}$ It is believed that it contains many functional substances to which the numerous positive effects of kefir on health may be attributed. ${ }^{6}$ In fact, it has been postulated that the longevity of Bulgarian peasants is partially due to consumption of this fermented milk. ${ }^{4}$

Kefir grains contain bacteria and yeasts living in symbiosis and this special symbiotic nature has made it difficult to identify and study the constituent microorganisms within kefir grains. ${ }^{6}$ It has been reported that the bacteria and yeasts of kefir, when cultured separately, either were not able to grow in milk or showed a lower biochemical activity, also making it more complicated to study the microbial population of kefir grains. ${ }^{3}$ Some of the bacteria that were identified in kefir include: Lactobacillus brevis, Lb. helveticus, Lb. kefir, Lb. viridescens, Lb. casei, Lb. kefiranofaciens, Lb. kefirgranum, Lb. parakefir, Lb. plantarum, Lb. acidophilus, Lb. delbrueckii, Lb. rhamnosis, Lb. paracasei, Lb. fructirorans, Lb. hilgardii, Lb. fermentum, Lb. riridescens, Lactococcus lactis subsp. lactis, Lactococcus lactis subsp. cremoris, Streptococcus thermophilus, Enterococci durans, Leuconostocs sp., Leuconostocs mesenteroides, Acetobacter sp., Bacillus sp., Bacillus subtilis, Micrococcus sp., Escherechia coli, Kluyveromyces lactis, Kluyveromyces marxianus, and Pichia fermentans. ${ }^{3,4,7}$ Metabolites produced by the yeasts add to the taste and mouthfeel of kefir and provide a milieu for the growth of kefir bacteria. ${ }^{3}$ Some of the yeasts that were identified in kefir include: Saccharomyces sp., Saccharomyces cerevisiae, Saccharomyces unisporus, Saccharomyces exiguus, Saccharomyces turicensis, Saccharomyces delbrueckii, Saccharomyces dairensis, Saccharomyces unisporus, Saccharomyces lipolytica, Candida pseudotropicalis, Candida friedrichii, Candida tenuis, Candida maris, Candida inconspicu, Candida lambica, Candida tannotelerans, Candida valida, Candida holmii, Candida kefir, Candida holmii, Torulaspora delbrueckii, Brettanomyces anomalus, Issatchenkia occidentalis, Pichia fermentans, and
Kluyveromyces marxianus. ${ }^{3,7}$ Both bacteria and yeasts in kefir grains are surrounded by a polysaccharide matrix, which contains a water-soluble branched glucogalactan, ${ }^{8}$ produced by lactobacilli within the grains. The polysaccharide, named kefiran, is composed of a hexasaccharide-repeating unit and has been reported to possess many health benefits. ${ }^{8}$

The health benefits of kefir in Eastern European countries have been identified since early times and are linked with general well-being there. ${ }^{3}$ Kefir has been found to stimulate the immune system ${ }^{4,9}$ and enhance the ability to digest lactose in lactose maldigestors. ${ }^{10}$ Kefir possesses antimicrobial activity in vitro against a wide variety of Gram-positive and Gramnegative bacteria, as well as some fungi. ${ }^{3,11}$ Kefir also seems to be a promising compound in terms of the enhancement of mucosal resistance to gastrointestinal pathogen infection. ${ }^{12,13}$ In addition, kefir was found to have antiallergic and antimutagenic effects. ${ }^{8,12,14}$ Kefir as a complex fermented milk, together with its cell-free fraction (KF), was able to exert beneficial effects on the immune system and prevent several types of cancer: ${ }^{15}$ Ehrlich carcinoma or Sarcoma 180, Lewis lung carcinoma, E-ascites carcinoma (EC), human mammary cancer (MCF-7), and human T-lymphotropic virus- (HTLV)positive malignant T-lymphocytes. ${ }^{16-19}$

The present study aims to test the cytotoxic, antiproliferative, and proapoptotic effects of a cell-free fraction of kefir on human T-lymphotropic virus type 1 (HTLV-1)-negative leukemia cell lines.

\section{Material and methods Cell line and cell culture}

Two HTLV-1-negative leukemia cell lines were used: CEM and Jurkat. CEM cells are human T-lymphoblastoid cells originally derived from peripheral blood of a 4-year-old Caucasian female with acute lymphoblastic leukemia. ${ }^{20}$ Jurkat cells were primarily established from the peripheral blood of a patient with acute lymphoblastic leukemia in relapse. The advantage of using Jurkat cells is that they have the same markers as normal lymphocytes. ${ }^{21}$

The cells were suspended in RPMI 1640 medium containing $25 \mathrm{mM}$ Hepes and L-glutamine supplemented with $10 \%$ fetal bovine serum (FBS), $100 \mu \mathrm{g} / \mathrm{mL}$ streptomycin, and $100 \mathrm{U} / \mathrm{mL}$ in penicillin, and were grown in a humidified incubator $\left(37^{\circ} \mathrm{C}\right)$ at $95 \%$ air and $5 \% \mathrm{CO}_{2}$. Cells were split every two days at a ratio of 1:4. Before seeding, the cell viability was tested by the trypan blue dye exclusion method. The cells were counted using a hemocytometer according to the following formula: cells $/ \mathrm{mL}=$ number of cells in five 
squares $/ 5 \times$ dilution factor $\times$ volume of suspension $\times 10^{4}$. For all experiments, cells were seeded at a density of $1 \times 10^{5}$. The test compound was added after 24 hours of seeding.

\section{Primary fresh cultures of human lymphocytes}

Human peripheral blood lymphocytes from healthy individuals were isolated using a Ficoll-isopaque gradient (1.077) for immediate growth (courtesy of the American University of Beirut Medical Center). These lymphocytes were grown, in the presence or absence of kefir, in complete growth medium consisting of RPMI 1640 supplemented with 20\% FBS, $2 \mathrm{mM}$ L-glutamine, $100 \mathrm{U} / \mathrm{mL}$ penicillin, and $100 \mu \mathrm{g} / \mathrm{mL}$ streptomycin for 24 hours. The effect of kefir on cytotoxicity and proliferation of the lymphocytes was determined using the methods described below, and the percentage change was determined in comparison to the control.

\section{Preparation of cell-free fraction of kefir}

Sterilized, pasteurized skimmed milk (150 mL) was inoculated with kefir grains (50 g). All inoculated milk samples were incubated at $20^{\circ} \mathrm{C}$ for 24 hours in a sealed glass container. At the end of fermentation, the milk was strained to remove the kefir grains. The yeast and bacteria in the filtrate were removed by centrifugation $(35,000 \mathrm{rpm}$ for 10 minutes at $4^{\circ} \mathrm{C}$ ) and filtration through a $0.22-\mu \mathrm{m}$ filter (Millipore, Billerica, MA). The kefir filtrates were then solidified using a centrivap concentrator and stored at $-20^{\circ} \mathrm{C}$ until required.

On the day of treatment, the solidified kefir was redissolved in media (RPMI 1640) and applied on the seeded cells.

\section{Cytotoxicity}

Cells were seeded into 96 -well plates at a density of $1 \times 10^{5}$ cells/well. After 24 hours of seeding, cells were treated with different concentrations of kefir or media alone for the controls. Cytotoxicity of kefir on the cell lines was assayed at 6, 24, and 48 hours using two methods: 1) Cytotoxicity Detection Kit (LDH; Roche, Mannheim, Germany) according to the instructions of the manufacturer. At the end of the treatment period, cells were centrifuged at $1400 \mathrm{rpm}$ for 10 minutes at $4^{\circ} \mathrm{C}$, after which the supernatant of each well was transferred to a new 96-well plate. The reaction mixture, supplied with the kit, was then added to the wells and kept in the dark at room temperature for 30 minutes. This method measures the amount of lactate dehydrogenase (LDH) released by dead cells. The conversion of tetrazolium salt into a red formazan dye product was measured colorimetrically at $492 \mathrm{~nm}$ using an enzyme-linked immunosorbent assay (ELISA) microplate reader; 2) Trypan blue exclusion method. This method measures the percentage viability by visually counting the dark cells compared to the live bright cells.

\section{Proliferation}

Cells were seeded into 96-well plates at a density of $1 \times 10^{5}$ cells/well. After 24 hours of seeding, cells were treated with different concentrations of kefir or media alone for the controls. Proliferation was measured at 6, 24, and 48 hours using two kits:

1. Cell Titer96 ${ }^{\circledR}$ Nonradioactive Cell Proliferation Kit (Roche) according to the instructions of the manufacturer. At the end of the treatment period, MTT (3-[4, 5-dimethylthiazol-2-yl]-2,5-diphenyltetrazolium bromide) was added to all wells of the plate and kept in a humidified incubator $\left(37^{\circ} \mathrm{C}\right)$ in $95 \%$ air and $5 \% \mathrm{CO}_{2}$ for four hours, after which a solubilization buffer was added and kept overnight. This is an MTT-based method that measures the ability of the mitochondria of metabolically active cells to convert tetrazolium salt into a blue formazan product, which is then measured colorometrically at $595 \mathrm{~nm}$;

2. Cell Proliferation Reagent (WST-1; Roche). At the end of the treatment period, water-soluble tetrazolium salt (WST-1) was added to the cells and kept in a humidified incubator $\left(37^{\circ} \mathrm{C}\right)$ in $95 \%$ air and $5 \% \mathrm{CO}_{2}$ for four hours. WST-1 is a tetrazolium salt that on contact with metabolically active cells is cleave to formazan by mitochondrial dehydrogenases. The formazan dye was then measured colorometrically at $450 \mathrm{~nm}$. The results were expressed as percentage of control.

\section{Flow cytometry}

Cells were seeded at a density of $1 \times 10^{5}$ cells $/ \mathrm{mL}$ in $3 \mathrm{~mL}$ of complete growth medium and, after 24 hours, treated with various noncytotoxic concentrations of kefir for 24 hours. Cells were centrifuged at $1200 \mathrm{rpm}$ at $4^{\circ} \mathrm{C}$ for five minutes. The pellet was then washed by resuspending it in $1 \mathrm{~mL}$ of ice-cold $1 \times$ phosphate-buffered saline $(\mathrm{PBS})$. Cells were centrifuged again under the same conditions as before and resuspended in $1 \mathrm{~mL}$ of $70 \%$ ethanol and stored at $-20^{\circ} \mathrm{C}$ for a few days. Later, cells were thawed and centrifuged at $1200 \mathrm{rpm}$ for five minutes, washed with $1 \mathrm{~mL}$ of ice-cold $1 \times$ PBS, centrifuged again, and then treated with $50 \mu \mathrm{L}$ of RNase and incubated for one hour 
and 15 minutes at $37^{\circ} \mathrm{C}$. The cells were then pelleted at $1200 \mathrm{rpm}$ for five minutes and these pellets were washed with $1 \mathrm{~mL}$ of $1 \times$ PBS then centrifuged and stained with $30 \mu \mathrm{L}$ of propidium iodide (PI). Cells were analyzed using a FACScan (Becton-Dickinson, San Jose, CA), which indicated the distribution of the cells into their respective cell-cycle phases based on their DNA content. G0/ G1 cells were $2 n$, S-phase cells were $>2 n$, but $<4 n$, while G2/M cells were $4 \mathrm{n}$. Cell DNA content was determined by CellQuest ${ }^{\mathrm{TM}}$ software (Becton-Dickinson). An increase in cells in the pre-G1 phase is indicative of an increase in apoptosis. The ratio of cells in the pre-G1 phase was compared to that of the control.

\section{Cell Death Detection ELISA assay}

Cell death was determined using a Cell Death detection ELISA (Roche). Cells were grown in RPMI 1640 complete growth medium as described before and treated with kefir for 24 hours. At the end of the experiment, the cells were harvested by centrifugation at $1200 \mathrm{rpm}$ and the pellet was lysed using a lysis buffer supplied with the kit. The supernatant was collected after centrifugation and used as a source for the antigen. The wells of the plate were coated with a primary antihistone monoclonal antibody and incubated overnight at $4^{\circ} \mathrm{C}$. The antigen was added then a secondary antibody conjugated to a peroxidase enzyme was added to each well. The changes in peroxidase activity were measured photometrically as optical density at $405 \mathrm{~nm}$ using 2, 2'-azino-di(3-ethylbenzthiazolin-sulfonate) (ABTS) as a substrate. An increase in optical density of the treated samples in relation to the control is indicative of an increase in apoptosis.

\section{RT-PCR for analysis of transforming growth factors and metalloproteinases}

Cells were grown in $3 \mathrm{~mL}$ of RPMI 1640 complete growth medium at a cell density of $1 \times 10^{5}$ cells $/ \mathrm{mL}$ and were treated with various noncytotoxic concentrations of kefir for 24 hours. Cells were collected and stored at $-80^{\circ} \mathrm{C}$ and the total RNA was extracted using an RNA extraction kit: NucleoSpin ${ }^{\circledR}$ RNA II kit (Macherey-Nagel GmbH and Co, KG, Duren, Germany) according to the manufacturer's instructions.

Reverse transcriptase polymerase chain reaction (RTPCR) (ReddyMix ${ }^{\mathrm{TM}}$ Reverse-iT One step Kit, ABgene, Epsom, UK) was used to amplify RNA. Two hundred ng of the RNA was converted to cDNA by RT-PCR using (Reverse-i $\mathrm{T}^{\mathrm{TM}} \mathrm{Blend}$ ) reverse transcriptase.

PCR was conducted in $25 \mu \mathrm{L}$ volume using oligonucleotide primers designed to detect the cDNA according to the following conditions. Table 1 shows the primers' sequences. To amplify the product, the RNA template was added to $0.5 \mu \mathrm{L}$ of each primer (forward and reverse) $(10 \mu \mathrm{M})$, and $0.5 \mu \mathrm{L}$ of reverse transcriptase $(50$ units $/ \mu \mathrm{L})$ were added to $12.5 \mu \mathrm{L} 2 \times$ ReddyMix $^{\text {TM }}$ RT-PCR Master Mix supplied with the kit containing $1.25 \mathrm{U} / 50 \mu \mathrm{L}$ of Thermoprine Plus DNA polymerase, dNTP mix with $0.2 \mathrm{mM}$ of each nucleotide and $1.5 \mathrm{mM}$ of $\mathrm{MgCl}$, and $10 \mu \mathrm{M}$ of each primer. This $14 \mu \mathrm{L}$ mixture was added to the RNA sample and the volume was adjusted to $25 \mu \mathrm{L}$ with RNase-free double distilled water. The PCR program for transforming growth factor-alpha ribonucleic acid (TGF- $\alpha$ RNA) was as follows: first strand synthesis at $47^{\circ} \mathrm{C}$ for 60 minutes, initial denaturation at $94^{\circ} \mathrm{C}$ for two minutes, followed by 30 cycles of denaturation for 45 seconds at $94^{\circ} \mathrm{C}$, annealing at $50^{\circ} \mathrm{C}$ (for TGF- $\alpha$, TGF- $\beta 1$, and matrix metalloproteinase-2 [MMP-2]) or $55^{\circ} \mathrm{C}$ (for MMP-9) for 45 seconds and elongation for 45 seconds at $72^{\circ} \mathrm{C}$ with the final step at $72^{\circ} \mathrm{C}$ for five minutes. Conditions used for the amplification of $\beta$-actin were similar except that amplification was performed for 15 cycles and the annealing temperature used was $50^{\circ} \mathrm{C}$. Fifteen microliters of the PCR products were run on $0.8 \%$ agarose gels stained with $4 \%$ ethidium bromide at 100 volts for 30 minutes. The resulting bands were visualized by ultraviolet (UV) light and photographed. $\beta$-actin was used as an internal control to ensure equal loading.

Table I Primer sequences used in reverse transcriptase polymerase chain reaction (RT-PCR)

\begin{tabular}{|c|c|c|}
\hline Gene & Size (Bp) & Sequence \\
\hline MMP-2 & 605 & forward 5'-CAGTTTTTCAAGACAGA TCATAAGCG-3', reverse 5'-TGCTCCTGCTTGAG-ATGTCG-3' \\
\hline MMP-9 & 266 & forward 5'-AAGCACATGCAGAATGAGTACCG-3', reverse 5'-GTGGGACAGCTTCTGGTCGAT-3'; \\
\hline$\beta$-Actin & 550 & forward 5'-ATGAAGATCCTGACCGAGCGT-3', reverse 5'-AACGCAGCTCAGTAACAGT-CCG-3'. \\
\hline TGF- $\alpha$ & 373 & forward 5' ATGTTGTTCCCTGCAAGTCC 3 ', reverse 3 'ACTATGGAGAGGGGTCGCTT 5' \\
\hline TGF- $\beta$ I & 661 & forward 5' GAAGTCACCCGCGTGCTAATGG 3', reverse 3' GGATGTAAACCTCGGACCTGTGTG 5' \\
\hline
\end{tabular}

Abbreviations: MMP, matrix metalloproteinase; TGF- $\alpha$, transforming growth factor-alpha; TGF- $\beta$ I, transforming growth factor-beta I; Bp, base pair. 


\section{Statistical analyses}

All experiments were carried out in triplicate. Results were reported as the mean value \pm standard deviation. Data were analyzed by one-way analysis of variance (ANOVA). The differences between the means of treated and control groups were tested for significance using Fisher's least significant differences at $P \leq 0.05$ (Fisher PLSD). An effect was considered significant when the value $( \pm)$ of mean difference between groups exceeded Fisher PLSD in the one-factor ANOVA test.

\section{Results \\ Cytotoxicity of kefir}

The maximum cytotoxic value, as determined by the trypan blue exclusion method was $42 \%$ for CEM and 39\% for Jurkat in the 48-hour treatment of $80 \mu \mathrm{g} / \mu \mathrm{L}$ (Figure 1). Since the cytotoxicity was still below $50 \%$ and the IC50 was not reached, all concentrations were used to assess the effect of kefir on proliferation.
The Cytotoxicity Detection Kit (LDH) was also used to determine the cytotoxicity of kefir. However, the results obtained were not reported because kefir had a high interference with the production of the red formazan dye, thus giving invalid values for the cytotoxicity. To test the effect of kefir on normal cells, T-lymphocytes obtained from healthy donors were treated with various concentrations of kefir. Figure 2 shows that there was no significant necrotic effect detected by treating normal T-lymphocytes with kefir.

\section{Effect of kefir on proliferation}

Cells were seeded in 96-well tissue culture plates and treated with kefir for 6, 24, and 48 hours. The effect of kefir on the proliferation of leukemia cells was measured using two kits: one based on an MTT method that measures the conversion of tetrazolium salt into a formazan product, and another one that uses the tetrazolium salt WST-1 which, when in contact with metabolically active cells, becomes

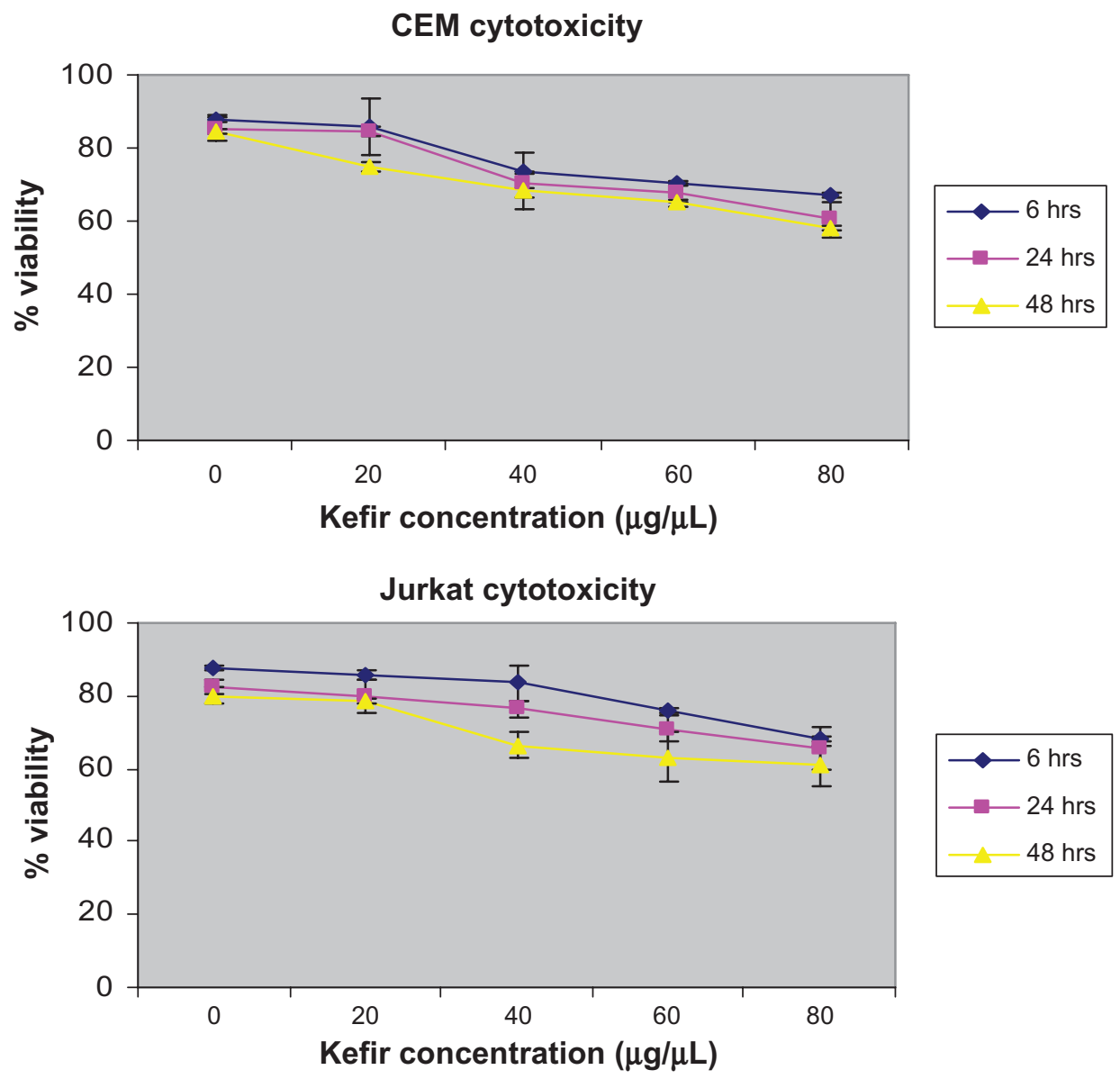

Figure I The cytotoxicity of kefir on CEM and Jurkat cells.

Note: Error bars represent the standard deviation. 


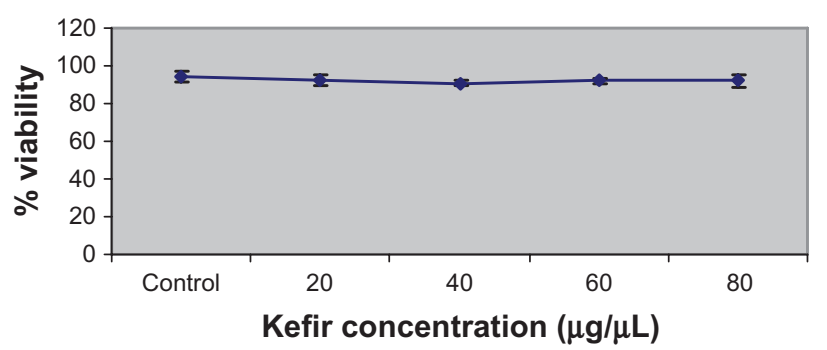

Figure 2 Effect of kefir on the viability of normal lymphocytes from the blood of healthy patients.

Notes: Error bars represent standard deviation. Kefir does not result in significant reduction in the viability of normal lymphocytes.

cleaved to formazan by mitochondrial dehydrogenases. Kefir was found to decrease the proliferation of both cell lines in a dose- and time-dependent manner. The percent reduction in proliferation by on $60 \mu \mathrm{g} / \mu \mathrm{L}$ treatment was found to be around $64.83 \%, 88.1 \%$, and $90.1 \%$ for 6,24 , and 48 hours for CEM cells, respectively, compared to $47.86 \%, 86.7 \%$, and $87.3 \%$ reduction at 6,24 , and 48 hours for Jurkat cells, respectively (Figure 3). In all subsequent experiments, the treatment was done by using 20,40 , and $60 \mu \mathrm{g} / \mu \mathrm{L}$ concentration of kefir for 24 hours. To test the effect of kefir on normal cells, T-lymphocytes obtained from healthy donors were treated with various concentrations of kefir for 24 hours; the maximum level in the decrease of proliferation recorded was only $8.2 \%$.

\section{Effect of kefir on cell-cycle arrest}

The effect of kefir on proliferation and cell-cycle progression of the cell line was tested using flow cytometry analysis. Kefir was found to induce a G0/G1 arrest and an increase in cells in the pre-G1 phase indicative of an increase in apoptosis. In the two HTLV-1 negative cell lines, a three-fold increase in cells in the pre-G1 phase was observed after treatment with kefir for 24 hours (Figure 4).

\section{Effect of kefir on apoptosis}

Cell Death Detection ELISA assay measures the cytosolic histone fragments, which are a hallmark of apoptosis, based on optical density. This experiment was used to further confirm the results obtained by flow cytometry. In both tested cell lines, a dose-dependent increase in apoptotic cells was
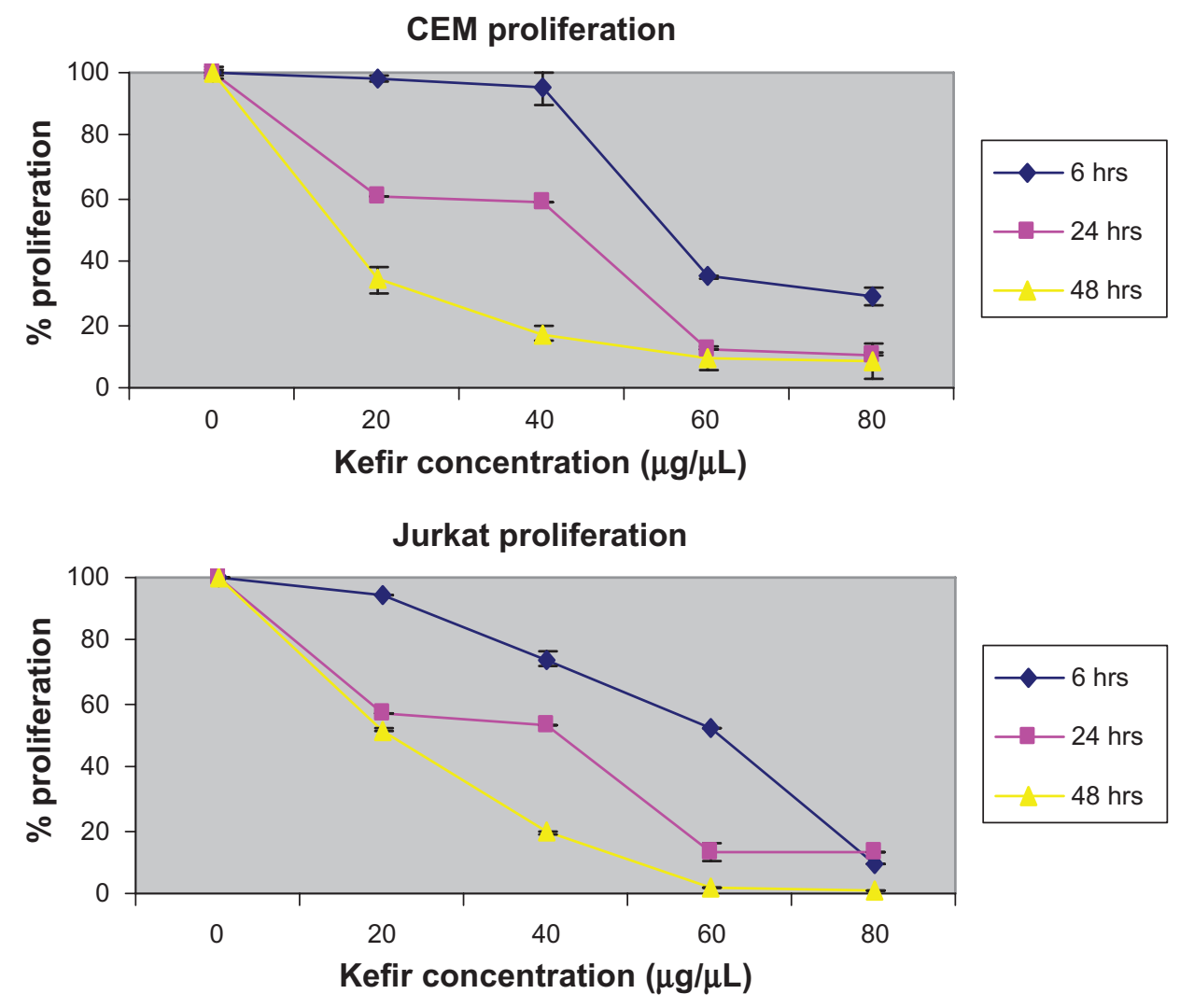

Figure 3 Effect of kefir on the proliferation of CEM and Jurkat cells.

Notes: The error bars represent standard deviation. Kefir causes a dose and time-dependent reduction in proliferation. 

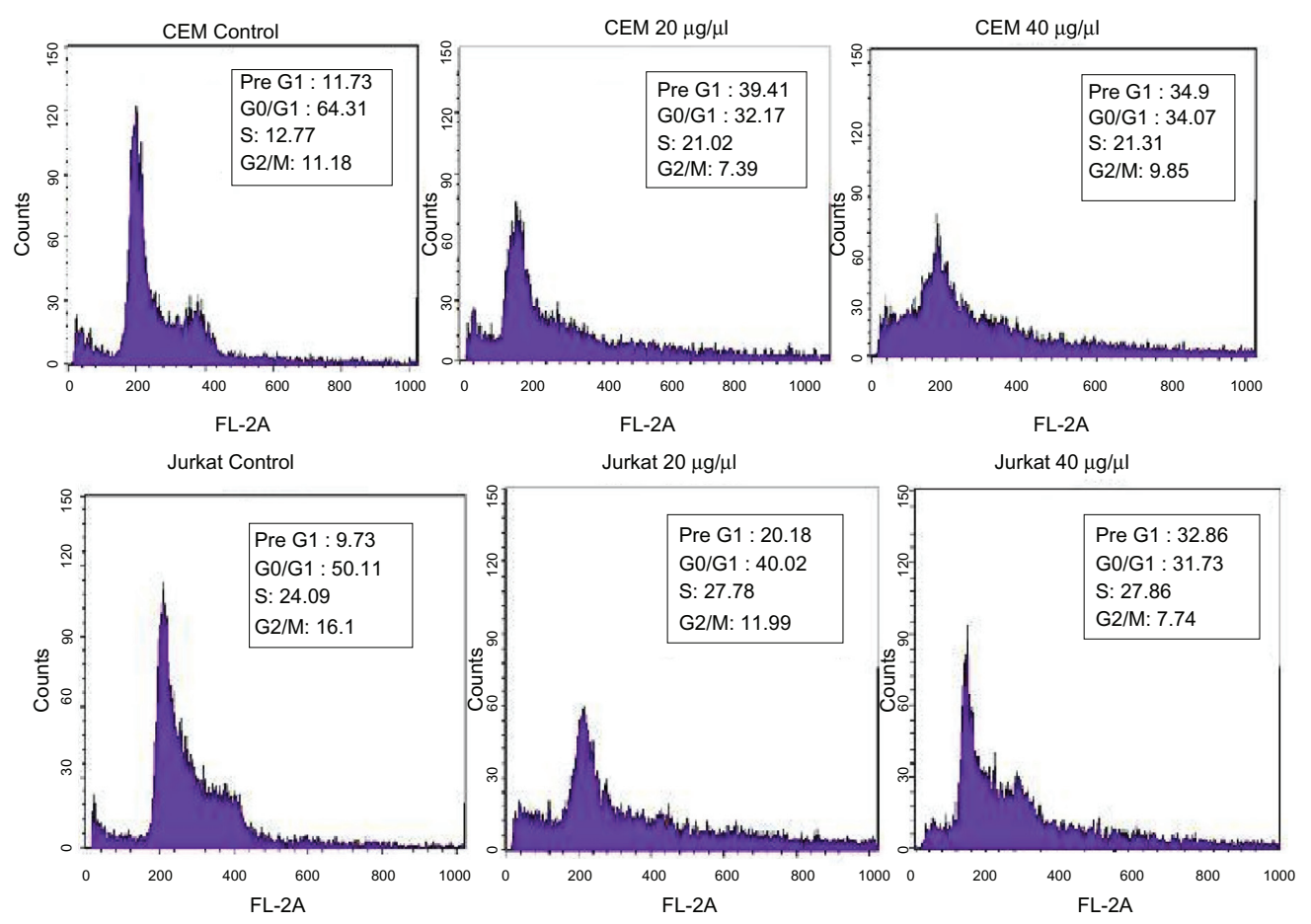

Figure 4 Effect of kefir on the cell cycle/apoptosis by flow cytometry on CEM and Jurkat cells. Results indicate that kefir causes a G0/GI arrest, as evidenced by the increase in the cells in the pre-GI phase.

detected after 24-hour treatment with noncytotoxic concentrations of kefir (Figure 5).

\section{Effect of kefir on transcriptional levels of transforming growth factors and metalloproteinases}

The transcriptional levels of transforming growth factors (TGF- $\alpha$ and TGF- $\beta 1$ ) and metalloproteinases (MMP-2 and MMP-9) were assayed using RT-PCR. The four treatments used in this experiment were control, $20 \mu \mathrm{g} / \mu \mathrm{L}, 40 \mu \mathrm{g} / \mu \mathrm{L}$, and $60 \mu \mathrm{g} / \mu \mathrm{L}$. TGFs are proteins belonging to the family of cytokines that promote regulation of proliferation, differentiation, and apoptosis. TGF- $\alpha$ is a cytokine that induces the proliferation and replication of cells by binding to the epidermal growth factor receptor (EGFR), ${ }^{22}$ whereas TGF- $\beta 1$ inhibits proliferation of activated T-lymphocytes by inhibiting mitosis. ${ }^{23}$ Treatment with kefir was found to decrease the transcriptional levels of TGF- $\alpha$ and increase the transcriptional levels of TGF- $\beta 1$ in both tested cell lines in a dose-dependent manner (Figure 6). MMPs are gelatinases that degrade the extracellular matrix, thus facilitating invasion and metastasis of cancerous cells. Kefir had no effect on the expression of MMP-2 mRNA, whereas MMP-9 expression was not detected in both cell lines (Figure 6). $\beta$-actin was used to ensure equal loading.

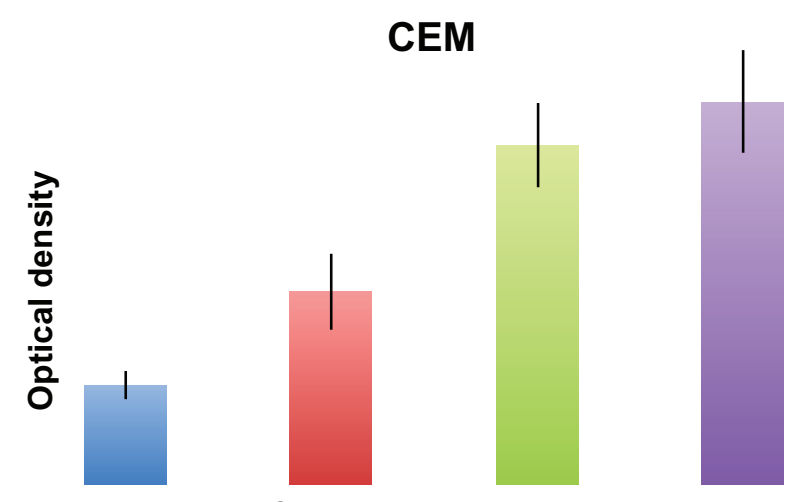

Kefir concentration $\mu \mathrm{g} / \mu \mathrm{L}$

\section{Jurkat}

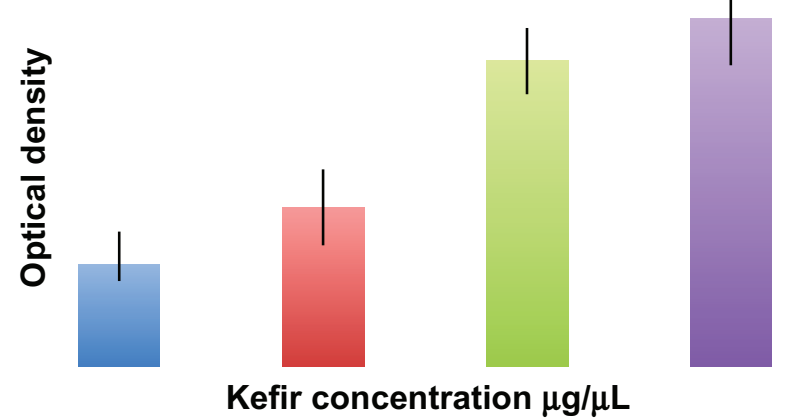

Figure 5 Effect of kefir on apoptosis using Cell Death ELISA kit, which quantitatively detects cytosolic histone-associated DNA fragments. Kefir causes an increase in DNA fragments, indicating an increase in apoptosis in both cell lines used. Abbreviation: ELISA, enzyme-linked immunosorbent assay. 


\begin{tabular}{|c|c|c|c|c|c|c|c|c|}
\hline \multicolumn{5}{|c|}{ CEM } & \multicolumn{4}{|c|}{ Jurkat } \\
\hline Kefir conc & 0 & 20 & 40 & 60 & 0 & 20 & 40 & 60 \\
\hline TGF $\alpha$ & $=$ & $=$ & & & 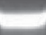 & 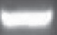 & $=$ & $\Rightarrow$ \\
\hline TGB- $\beta 1$ & & & l & tr & $=$ & - & 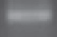 & - \\
\hline MMP-2 & - & $=$ & $=$ & $=$ & 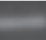 & - & - & 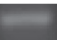 \\
\hline MMP-9 & & & & & & & & \\
\hline B-actin & 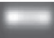 & 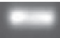 & $=$ & - & 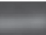 & 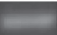 & - & - \\
\hline
\end{tabular}

Figure 6 The effect of kefir on the transcriptional level of TGF- $\alpha$, TGF $\beta$ I, MMP-2 and MMP-9 in CEM and Jurkat cells.

Abbreviations: Conc, concentration; MMP, matrix metalloproteinase; TGF- $\alpha$, trans forming growth factor-alpha; TGF- $\beta$ I, transforming growth factor-betal.

\section{Discussion}

The results obtained in this study indicate that kefir exhibits an antiproliferative and proapoptotic effect in HTLV-1negative malignant T-lymphocytes. Similar results have been recently reported on HUT-102 malignant T-lymphocytes infected with the HTLV-1 virus. ${ }^{19}$ This is also consistent with the previously reported antitumor effect of kefir on many types of cancer, such as slowing down Sarcoma 180 growth in mice by introducing kefir both orally and intraperitonially, ${ }^{16}$ inhibition of pulmonary metastasis in Lewis lung carcinoma by orally administered polysaccharide fraction from kefir grains,${ }^{17}$ reduction of proliferation and apoptosis induction in Sarcoma 180 in vitro, ${ }^{4}$ as well as the regression of human mammary cancer demonstrated by Kubow et al. ${ }^{5}$ However, the antitumor effect of kefir on HTLV-1-negative leukemic cancers has not been previously reported.

In this study, kefir induced apoptosis in cancerous cells at concentrations $40 \mu \mathrm{g} / \mu \mathrm{L}, 60 \mu \mathrm{g} / \mu \mathrm{L}$, and $80 \mu \mathrm{g} / \mu \mathrm{L}$. The cytotoxicity of the compound was analyzed by determining the percentage of viable cells remaining after 6,24 , and 48 hours of incubation in order to utilize these concentrations as noncytotoxic. $\mathrm{The}_{\mathrm{IC}}$ concentration was not found, since kefir significantly inhibited the proliferation of both CEM and Jurkat cells at concentrations less than $50 \%$ cytotoxicity. Due to the high viscosity of kefir, it was preferable not to use higher concentrations in order to avoid color interference in the absorbance results.

The effect of kefir on cytotoxicity of normal human lymphocytes was also studied. Kefir is an acidic product that could exhibit necrotic effects on normal as well as leukemic lymphocytes thereby abolishing any therapeutic application for kefir. No cytotoxic/necrotic effect on the normal cells was observed, as the viability remained above $90 \%$ at $80 \mu \mathrm{g} / \mu \mathrm{L}$, which was the highest concentration of kefir used. This is in line with that reported by Chen et $\mathrm{al}^{18}$ where the kefir extract did not suppress the growth of normal human mammary cells, indicating that kefir contains bioactive ingredients that exert a growth suppressive effect that is specific to cancer cells.

To further investigate kefir's effect on proliferation, the levels of TGF- $\alpha$ and TGF- $\beta 1$ were analyzed. Kefir caused the downregulation of TGF- $\alpha$ and the upregulation of TGF- $\beta 1$ in both cell lines used. TGFs are a large family of cytokines that have various effects on cells, such as regulating proliferation, differentiation, and apoptosis. TGF- $\alpha$ is a cytokine that induces the proliferation and replication of cells through binding to the epidermal growth factor receptor (EGFR). ${ }^{22}$ Binding to EGFR induces autophosphorylation of the receptor, triggering a phosphorylation cascade with some targets binding Src and JAK-2. Another consequence of EGFR-binding is the activation of the proto-oncogene Ras. It has been reported that Ras overexpression may lead to the development of skin papillomas in mice as well as other types of cancer. ${ }^{24}$ Furthermore, TGF- $\alpha$ has been found to inhibit apoptosis in murine gastric pit cells through the nuclear factor- $\mathrm{KB}(\mathrm{NF}-\mathrm{\kappa B})$ pathway, causing an upregulation of Bcl-2 antiapoptotic proteins. ${ }^{23}$ TGF- $\beta$, on the other hand, is a proapoptotic TGF; Saeki et $\mathrm{al}^{25}$ showed that TGF- $\beta$ led to the induction of cell density-dependent apoptosis in human leukemia HL-60 cells. TGF- $\beta$ was also shown to induce Fas-mediated apoptosis in human T-cells, ${ }^{26,27}$ and to promote apoptosis in B-cells through the NF-jB/Rel pathway. ${ }^{28}$

Analysis of the cell-cycle distribution, where the inhibition took place due to kefir treatment, revealed that the cell-cycle inhibition occurred at the $\mathrm{G} 0 / \mathrm{G} 1$ phase as a result of the increase in the number of cells in the Pre-G1 phase. This G0/G1 arrest may also indicate that kefir induces apoptosis in malignant cell lines. This proapoptotic effect of kefir was further confirmed using Cell Death Detection ELISA assay. In this technique, the cells were lysed and the collected supernatant, containing the antigen, was added to the wells of the plate coated with a primary antihistone monoclonal antibody. Then a secondary antibody (complementary to histone proteins), conjugated to a peroxidase enzyme, was added to each well, inducing a change in color upon addition of the ABTS substrate. In the present study, both cell lines treated with kefir exhibited an increase in optical density indicating an increase in apoptosis. In future corresponding studies, the effect of kefir on the levels of the proapoptotic protein Bax and p53, the cyclin-dependent kinase inhibitor $\mathrm{p} 21$, and antiapoptotic protein Bcl- $2 \alpha$ could be tested.

Finally, the expression of metalloproteinases was investigated to study the effect of kefir on the metastatic ability of 
leukemic cell lines. Unfortunately, MMP-9 expression was not detected in either of the cell lines, whereas the level of MMP-2 expression was not altered by kefir treatment. However, this does not rule out the possibility of kefir affecting metastasis; it would be useful to determine the activity of metalloproteinases by on kefir treatment using zymograms since kefir could affect either posttranslational modifications, or the activity of metalloproteinases.

\section{Conclusion}

This study, along with the study on HUT-102 cells ${ }^{19}$ shows the beneficial effects of kefir on human T-lymphotropic virus type I negative and positive malignant T-cells. Kefir reduces proliferation and induces apoptosis of leukemic cells without exhibiting any significant necrotic effect on normal cells. Based on the above data, kefir should be further evaluated clinically in vivo in patients with adult T-cell leukemia.

\section{Disclosure}

The authors report no conflicts of interest in this work. This work was funded by the Lebanese American University Research Council (URC-T-2010-107).

\section{References}

1. Armitrage JO, Longo DL. Malignancies of lymphoid cells. In: Kasoer DL, Braunwald E, Fauci AS, et al, editors. Harrison's Online: Harrison's Principles of Internal Medicine. 16th ed. New York, NY: McGraw-Hill; 2005.

2. Pui C, Evans W. Treatment of acute lymphoblastic leukemia. $N$ Engl $J$ Med. 2006;345:266-278.

3. Farnworth E. Kefir-a complex probiotic. Food Sci Technol Bull. 2005;2:1-17.

4. Liu JR, Wang SY, Lin YY, Lin CW. Antitumor activity of milk kefir and soy milk kefir in tumor-bearing mice. Nutr Cancer. 2002;44:182-187.

5. Kubow S, Chan LH, Chen C, Fotouhinia M. World Intellectual Property Organization. Kefir extract as anti-cancer agent. Geneva, Switzerland: World Intellectual Property Organization; 2001;WO/2001/09591.

6. Lopitz-Otsoa F, Rementeria A, Elguezabal N, Garaizar J. Kefir: a symbiotic yeasts-bacteria community with alleged healthy capabilities. Rev Iberoam Micol. 2006;23:67-74.

7. Abraham A, de Antoni G. Characterization of kefir grains grown in cows' milk and in soya milk. J Dairy Res. 1998;66:327-333.

8. Lee MY, Ahn KS, Kwon OK, et al. Anti-inflammatory and anti-allergic effects of kefir in a mouse asthma model. Immunobiology. 2007;212: 647-654.

9. Thoreux K, Schmucker DL. Kefir milk enhances intestinal immunity in young but not old rats. $J$ Nutr. 2001;131:807-812.

Cancer Management and Research

\section{Publish your work in this journal}

Cancer Management and Research is an international, peer-reviewed open access journal focusing on cancer research and the optimal use of preventative and integrated treatment interventions to achieve improved outcomes, enhanced survival and quality of life for the cancer patient The journal welcomes original research, clinical \& epidemiological
10. De Vrese M, Keller B, Barth CA. Enhancement of intestinal hydrolysis of lactose by microbial b-galactosidase (EC 3.2.1.23) of kefir. Br J Nutr. 1992;67:67-75.

11. Garrote GL, Abraham AG, de Antoni GL. Preservation of kefir grains, a comparative study. Lebenson Wiss Technol. 1997;30:77-84.

12. Liu JR, Wang SY, Chen MJ, Yueh PY, Lin CW. The anti-allergenic properties of milk kefir and soymilk kefir and their beneficial effects on the intestinal microflora. J Sci Food Agricul. 2006;86:2527-2533.

13. Marquina D, Santos A, Corpas I, Munoz J, Zazo J, Pienado JM. Dietary influence of kefir on microbial activities in the mouse bowel. Lett Appl Microbiol. 2002;35:136-140.

14. Guzel-Seydem ZB, Seydem AC, Greene AK, Tas T. Determination of antimutagenic properties of acetone extracted fermented milks and changes in their total fatty acid profiles including conjugated linoleic acids. Int J Dairy Technol. 2006;59:209-215.

15. LeBlanc A, Matar C, Farnworth E, Perdigon G. Study of cytokines involved in the prevention of a murine experimental breast cancer by kefir. Cytokine. 2006;34:1-8.

16. Shiomi M, Sasaki K, Murofushi M, Aibara K. Antitumor activity in mice of orally administered polysaccharide from kefir grain. Jpn JMed Sci Biol. 1982;35:75-80.

17. Furuwaka N, Matsuoka A, Takahashi T, Yamanaka Y. Anti-metastatic effect of kefir grain components on Lewis Lung Carcinoma and highly metastatic B16 melanoma in mice. J Agricult Sci. 2000;45:62-70.

18. Chen C, Chan HM, Kubow S. Kefir extracts suppress in vitro proliferation of estrogen-dependent human breast cancer cells but not normal mammary epithelial cells. J Med Food. 2007;10:416-422.

19. Rizk S, Maalouf K, Baydoun E. The anti-proliferative effect of kefir cellfree fraction on HuT-102 malignant T-lymphocytes. Clin Lymphoma Myeloma Leuk. 2009:S198-S203.

20. Foley GE, Lazarus H, Farber S, Uzman BG, Boone BA, Mccarthy RE. Continuous culture of human lymphoblasts from peripheral blood of a child with acute leukemia. Cancer. 1965;18:522-529.

21. Harakeh S, Diab-Assaf M, Niedzwiecki A, Khalife J, Abu-El-Ardat K, Rath M. Apoptosis induction by Epican Forte in HTLV-1 positive and negative malignant T-cells. Leuk Res. 2006;30:869-881.

22. Jorissen RN, Walker F, Pouliot N, Garrett, TPJ, Ward CW, Burgess AW. Epidermal growth factor receptor: mechanisms of activation and signalling. Exp Cell Res. 2003;284:31-53.

23. Kanai M, Konda Y, Nakajima T, Izumi Y, Takeuchi T, Chiba T. TGF- $\alpha$ inhibits apoptosis of murine gastric pit cells through an NF-KBdependent pathway. Gastroenterology. 2001;121:56-67.

24. Harris RC, Chung E, Coffey RJ. EGF Receptor ligands. Exp Cell Res. $2003 ; 284: 2-13$.

25. Saeki K, et al. Cell density-dependent apoptosis in HL-60 cells, which is mediated by an unknown soluble factor, is inhibited by transforming growth factor beta 1 and overexpression of Bcl-2. J Biol Chem. 2000;272:3-10.

26. Cerwenka A, Kovar H, Majdic O, Holter W. Fas- and activation-induced apoptosis are reduced in human $\mathrm{T}$ cells preactivated in the presence of TGF-beta 1. J Immunol. 1996;156:459-464.

27. Chen W, Jin W, Wahl SM. Engagement of cytotoxic T lymphocyteassociated antigen 4 (CTLA-4) induces transforming growth factor $b$ (TGF-b) production by murine CD4+ T cells. J Exp Med. 1998;188: 1849-1857.

28. Patil S, et al. Smad7 is induced by CD40 and protects WEHI 231 B-lymphocytes from transforming growth factor-b-induced growth inhibition and apoptosis. J Biol Chem. 2000;275:38363-38370.

\section{Dovepress}

studies, reviews \& evaluations, guidelines, expert opinion \& commentary, case reports \& extended reports. The manuscript management system is completely online and includes a very quick and fair peerreview system, which is all easy to use. Visit http://www.dovepress.com/ testimonials.php to read real quotes from published authors. 